\title{
Undeclared work and legal instruments for combating it in Spain*
}

\author{
Fernando Fita Ortega** \\ Professor at the Department of Labour Law and Social Security \\ Law Faculty. University of Valencia
}

Recibido: 2.2 .2018

Aceptado: 24.2.2018

https://doi.org/10.20318/sllerj.2018.4434

\begin{abstract}
This article analyses the measures adopted in Spain to combat undeclared work, although only with respect to activities included in the scope of the Spanish Workers' Statute (workers under employment agreements). For the purposes of this analysis, the measures have been broken down into three main groups: control measures; measures to combat illegal employment and, finally, measures to promote legal employment. The paper concludes with some reflections on the effectiveness of these measures.

Keywords: undeclared work, control instruments, promotion of declared work, sanctions against undeclared work, Spain.
\end{abstract}

1. The need to combat unreported employment. Undeclared work or unreported employment (i.e. "any paid activities that are lawful as regards their nature but not declared to the public authorities", such that they do not comply, fully or partly, with the obligations related to the provision of an economic activity $^{2}$ ) has always been perceived as a threat that affects many areas: the labour market, since it favours unfair competition; the social protection system, as a risk to its long-term future; and the rights of workers, mainly those who work on the informal market, but also those who are in formal employment, because their working conditions may suffer downward pressure due to unfair competition stemming from undeclared work.

From this perspective, undeclared work is fraud that has serious consequences for society as a whole, where those who comply with the established rules suffer the effects twice over: firstly, because those who are working off the books do not contribute as they should to the sustainability of public finances, and in particular to the public social protection system, thus forcing those who declare their

\footnotetext{
* This article was written in the framework of the Project "Public social protection instruments for the management of labour change”, DER2014-52549-C4-4-R (National R\&D “Research Challenges" Plan, Ministerio de Economía y Competitividad).

*** fernando.fita@uv.es

${ }^{1}$ Communication from the Commission on Undeclared Work COM (1998) 219 final, Brussels, 07.04.1998.

${ }^{2}$ Whether they be existing administrative, tax, or social security obligations, or any other obligation resulting from civil legislation and, in general, from all laws that regulate both self-employment and salaried work. In this regard, Report 2/1999 of the Spanish Economic and Social Committee (21 April 1999) defined the shadow economy as "all activities relating to the production of goods and the rendering of services for the market that evade both tax-based laws, in the broader sense, and any other type of economic legislation, including labour regulations, but also others, such as those relating to the environment, technical standards, safety, etc." This definition demonstrates the economic aspect of undeclared work, to which the attention of the legislator is drawn.

http://www.CES.es/Documents/10180/18510/inf00299

On the problems of definition, see IGARTÚA MIRÓ, "El empleo irregular en España: puntos críticos," Trabajo y Derecho No. 1/2015. pp. 18 et seq.
} 
work to shoulder this financial burden; and secondly, because those in regular employment receive fewer services than they would if everyone contributed their share to public spending. ${ }^{3}$

The pressure of irregular migration on EU Member States, ${ }^{4}$ together with the current economic situation in these countries resulting from the 2008 crisis, has brought with it renewed concern about the need to combat undeclared work. In this regard, it has been stated that undeclared work is an obstacle to the growth of employment and, consequently, to the growth of the economy in a period of special difficulty for European economies. ${ }^{5}$ Moreover, it has been claimed that the possibility of finding employment in the underground economy contributes to a "pull factor" for illegal immigration into the EU. ${ }^{6}$

The measures against undeclared work also respond, therefore, to the objective of seeking "legal, orderly, responsible and employment-related immigration". ${ }^{7}$ From this point of view, a first conclusion can be drawn regarding the renewed concern of states with regard to unreported employment. In the present context we see undocumented workers (migrant workers, in particular) as uncooperative people who do not contribute financially to support the Welfare State - while claiming benefits - and who are a threat to economic growth in the country that supports them. Consequently, irregular migration is considered a threat that must be controlled. An analysis of this discourse would, however, go beyond the objectives of this article.

2. The measures proposed to control undeclared work. As a result of the approaches described above, states have introduced various initiatives to support the fight against undeclared work in a period of economic crisis, a crisis that has been taken into consideration when justifying the various measures adopted. ${ }^{8}$ In the case of Spain, the latest of these initiatives is included in the Plan to fight irregular work and social security fraud for the period 2012-2013 (Plan de lucha contra el empleo irregular y el fraude a la Seguridad Social para el periodo 2012-2013), approved by the Council of Ministers on 27 April 2012. ${ }^{9}$ This action plan aims to achieve four major objectives, including, firstly, bringing the underground economy to the surface, in order to regularise working conditions and generate greater income for the social security system through the payment of social contributions. ${ }^{10}$

The measures adopted in Spain, as a result of the initiatives adopted under action plans such as that outlined above to promote regular employment and to combat undeclared work, may be classified from an employment perspective into three broad categories: control measures, measures to combat illegal employment and, finally, measures to promote legal employment.

2.1. Control measures. Historically, the regularity and legality of work has mainly been controlled by the Labour Inspectorate, ${ }^{11}$ an organisation that was originally tasked with the mission of "ensuring compliance with the legal provisions relating to working conditions and the protection of workers in

\footnotetext{
${ }^{3}$ expressed in the Plan Integral de Prevención y Corrección del Fraude Fiscal, Laboral y a la Seguridad Social (March 2010) pp. 11 and 37. http://www.agenciatributaria.es/static files/AEAT/Contenidos_Comunes/La_Agencia_Tributaria/Sala de Prensa/Plan int prev corr fraude.pdf

${ }^{4}$ Communication from the Commission - Stepping up the fight against undeclared work, COM (2007) 628 final. Brussels, 24.10.2007. http://eur-lex.europa.eu/legal-content/es/TXT/PDF/?uri=CELEX:52007DC0628\&from=IT

${ }^{5}$ Thus states the preamble to Royal Decree-Law 5/2011, of 29 April, on measures for the regularisation and control of irregular employment and the promotion of housing rehabilitation.

${ }^{6}$ This is reflected in the second recital of Directive 2009/52/EC of 18 June 2009, providing for minimum standards on sanctions and measures against employers of illegally staying third-country nationals.

${ }^{7}$ Preamble to Law 13/2012, of 26 December, on combating irregular employment and social security fraud.

${ }^{8}$ This is the case both in Royal Decree-Law 5/2011, of 29 April, and in Law 13/2012, of 26 December, mentioned above.

${ }^{9}$ For an analysis of the most recent measures to combat undeclared work, see BAVIERA PUIG, I. "Avances en la lucha contra el empleo irregular y el fraude a la seguridad social". Aranzadi Social No 9/2014. With regard to the 2012 Plan to fight irregular work, MARTÍNEZ RAFECAS, D. El Plan de Lucha contra el empleo irregular y el fraude a la Seguridad Social: balance y perspectivas. Ministry of Employment and Social Security. 2014. See also PÉREZ AGULLA, S. "Plan de lucha contra el empleo irregular y el fraude a la seguridad social". Revista española de Derecho del Trabajo, No 155/2012.

${ }^{10}$ As well as this objective, the programme aims to: combat fraud by introducing incentives related to employment policies (such as credits or reductions in employer contributions to social security); fight existing unemployment benefits fraud; and uncover cases of social security benefits fraud.

${ }^{11}$ Although other bodies also carry out control duties. This is the case with the body that manages social contributions (General Treasury of Social Security) or the body that deals with unemployment benefits (Public State Employment Service)
} 
the exercise of their profession". ${ }^{12}$ Along with these functions, the Inspectorate has also taken on control duties in other areas, such as workplace health and safety and the social security system. ${ }^{13}$

It therefore stands to reason that one of the first steps taken after the adoption of Law 13/2012, to combat irregular employment and social security fraud, was to strengthen the institution of the Labour Inspectorate, an objective that has been achieved through various measures: ${ }^{14}$

a) Providing the inspection services with more personnel - particularly striking in a period in which, as a consequence of the crisis and the need to contain public spending, there have been significant cuts in public employment ${ }^{15}$ - and giving inspectors greater powers by regulating their access to electronic documents, among other aspects. ${ }^{16}$

b) Specifying ${ }^{17}$ and increasing ${ }^{18}$ the list of bodies on which the obligation to collaborate with the Labour Inspectorate falls, and classing this duty as an "active" obligation (providing data, reports and relevant background information within the scope of its responsibilities) and not only as a "passive" obligation (providing the information requested to the Inspectorate). ${ }^{19}$

c) Adding new grounds for extending the period allowed to complete the inspection procedures, although there is a limit to the time granted for an extension. Thus, current regulations establish that the maximum period of nine months for carrying out inspection activitie ${ }^{20}$ may only be extended for a new maximum period of nine months (previously there was no time limit for this extension of inspection activities) in the following cases: when the inspection activities are particularly difficult and complex; ${ }^{21}$ when in the course of the activities it is found that the subject of the inspection has obstructed the inspection body or concealed any of its activities or the people who perform them; or, lastly, when the inspection requires international administrative cooperation. ${ }^{22}$

\footnotetext{
${ }^{12}$ Article 3(1)(a) of Convention No 81 of 1947, on labour inspection in industry and commerce.

${ }^{13}$ In this regard, Article 12 of Law 23/2015, of 21 July, on the structure of the labour and social security inspection system, entrusts the Inspectorate with the task of monitoring and demanding compliance with legal provisions and regulations in applications, registrations, affiliations, worker registration and deregistration, contribution and collection of social security system payments, and with regulations related to access to and use of social security benefits.

${ }_{14}$ Provided for, respectively, in: Article 5(3)(3) in fine; Article 9; Article 14(2); and the eighth additional provision of repealed Law 42/1997, of 14 November, on the Labour Inspectorate - all these articles were introduced by Law 13/2012, to combat irregular employment and social security fraud. Currently, 13(3)(c), Article 16, and Article 21(4) of Law 23/2015, of 21 July, on the structure of the labour and social security inspection system.

${ }^{15}$ Royal Decree-Law 3/2015, of 22 March, which provides for an extraordinary and additional offer of public employment to combat fraud both in the area of taxation and in the area of laws relating to labour and social contributions.

${ }^{16}$ The promotion of digital administration in recent times justifies the regulation of companies' digital documents. In this regard, see GIL VILLANUEVA, “Artículo 3. Modificación de la Ley 42/1997, de 14 de noviembre, ordenadora de la Inspección de Trabajo y Seguridad Social ", in CAMINO FRÍAS (coord.) et al. Lucha contra el empleo irregular y el fraude a la Seguridad Social. Thomson Reuters. 2013. pp. 148 and 149.

${ }^{17}$ In this way, from the generic reference, before Law 13/2012, to "Public Administrations and all people exercising public functions", a more precise list is now provided: "authorities, whatever their nature, representatives of the bodies of the General State Administration, of the Administrations of the Autonomous Communities and of local entities; autonomous bodies and public business entities; chambers and councils, professional colleges and associations; all other public entities, and those who, in general, exercise public functions" (Article 9(1) Law 13/2012).

${ }^{18}$ The bodies that must provide information to the Labour Inspectorate now also include the General Council of Notaries and the social welfare mutuals, which were not previously listed among the agencies affected by said obligation.

${ }^{19}$ With regard to this obligation to collaborate, the law (Article 16(6) of Law 23/2015) sets as limits to these obligations of assistance and collaboration the legally established limitations regarding the privacy of the person, the secrecy of correspondence, and information provided to the Public Administrations for exclusively statistical purposes. Furthermore, the gathering of personal data not collected from the interested party by Inspectorate officials in the exercise of their powers will not require express and unequivocal notification of the interested parties as required by Article 5(4) of Organic Law 15/1999, of 13 December, on the protection of personal data (Article 16(11)). Nor will the submission to the Inspectorate of personal data subject to automated processing require the consent of the affected party (Article 16(3)).

${ }^{20}$ Which must be respected unless the delay is attributable to the subject of the inspection or to dependent persons (Article 21(4) Law 23/2015).

${ }^{21}$ These situations are defined in Article 17 of Royal Decree 138/2000, of 4 February, approving the regulation of the organisation and functioning of labour and social security inspection.

${ }^{22}$ This last reason, which was introduced by Law 25/2009, of 22 December, was, until the adoption of Law 13/2012, the only grounds for extending the inspection period.
} 
Along with this extension of the maximum periods allowed for completing inspection activities, the maximum period during which they may be suspended has been increased from three to five months, incorporating some exceptions to said maximum period: that the interruption is caused by the subject of the inspection or dependent persons, or when it has been found to be impossible to continue the inspection activities since a court ruling that may affect the outcome remains pending.

d) Improving the system for notification of the administrative acts of the Inspectorate, regulating electronic notification of the administrative acts of the Labour Inspectorate through its $\mathrm{Pu}$ blic Notice Board, ${ }^{23}$ making it mandatory for said notifications to comply with Organic Law 15/1999, of 13 December, on the protection of personal data.

These legislative initiatives were retained in Law 23/2015, of 21 July, on the structure of the labour and social security inspection system. ${ }^{24}$ This law, in addition to an administrative reorganisation of the state services and the autonomous community services of the Inspectorate, provides for the possibility of creating, within the State Labour and Social Security Inspection Agency, a National Anti-Fraud Office, as the body in charge of promoting and coordinating the implementation of measures to combat undeclared work, irregular employment, and social security fraud, and any other measures that become necessary. ${ }^{25}$ But what is surely most noteworthy in this new regulation of the Labour Inspectorate are the provisions regarding the presumption of certainty of facts related to undeclared work that are set down in the communications drawn up in compliance with the agreements or cooperation instruments with the Labour and Social Security Inspectorate, and which are carried out by officials that represent the Authority or are the agents thereof; ${ }^{26}$ this is also the case for facts verified by the Authorities of the Member States of the European Union with powers equivalent to those of the Labour and Social Security Inspectorate. ${ }^{27}$ Said presumptions are in addition to the traditional presumption of certainty of the facts set forth in the payment and infringement notices resulting from the checks carried out by the Labour Inspectorate. ${ }^{28}$

On the other hand, collaboration mechanisms between the Labour Inspectorate and other bodies and public authorities that participate in the fight against undeclared work have been stepped up. This has been achieved through the creation of a Special Unit of Collaboration and Support for Courts and Tribunals and the State General Prosecutor's Office in the fight against irregular employment and social security fraud. The function of this Unit, created by Order ESS/78/2014, of 20 January, ${ }^{29}$ is to collaborate and provide assistance in the prosecution of crimes related to unreported employment and social security fraud and, in particular, in the tasks of inspection, coordination, advice and support that may be necessary. To this end, it is envisaged that this Unit will provide the courts and the Public Prosecutor with the necessary reports, gathering and including, as the case may be, the information provided in the rest of the units that make up the Labour and Social Security Inspection System. ${ }^{30}$

${ }^{23}$ Following Law 15/2014, of 16 September, on streamlining the public sector and other administrative reform measures, these notifications are published on the Single Public Notice Board of the Official State Gazette.

${ }^{24}$ Repealing Law 42/1997.

${ }^{25}$ Second additional provision of Law 23/2015. According to the preamble to this regulation, this Office seeks to deal with fraud globally, given its far-reaching dimension, since "fraud not only supposes an undue drawdown of resources from the social security system (generation or use of undue benefits) or a failure to contribute to its cost (total or partial absence of social contributions). Fraud is linked, most of the time, to cases of labour exploitation in which workers are denied the most elementary rights, the most important of which is the recognition of their status as workers, as occurs in a situation of undeclared work".

${ }^{26}$ Article 16(8) Law 23/2015.

${ }^{27}$ Article 16(10) Law 23/2015.

${ }^{28}$ A presumption currently set down in Article 23 of Law 23/2015.

${ }^{29}$ The sixth final provision, entitled "Collaboration in the fight against irregular employment and social security fraud" granted the government a period of six months to create, within the General Directorate of the Labour and Social Security Inspectorate of the Ministry of Employment and Social Security, a Special Unit of Collaboration and Support for Courts and Tribunals and the State General Prosecutor's Office in the fight against irregular employment and social security fraud, organically and functionally dependent on the Central Authority of the Labour and Social Security Inspectorate.

${ }^{30}$ Article 2 of Order ESS/78/2014. 
The latest initiatives against undeclared work also seek to involve parties from labour relations and, in general, all of society. In this regard, Royal Decree-Law 5/2011, of 29 April, ${ }^{31}$ for cases involving companies that resort to contract arrangements, introduced the obligation (later set forth in Law $13 / 2012$ ) to check, prior to the start of the contracted activity and during the entire period of the contract, the affiliation and registration of the contracted workers with social security. ${ }^{32}$ This obligation falls upon those who contract or subcontract works or services that correspond to their registered company activity, ${ }^{33}$ or that are provided on an ongoing basis ${ }^{34}$ in their workplace (in which case it is irrelevant if the works and services correspond to the activity of the company in question).

The verification obligation introduced by Royal Decree-Law 5/2011, and in contrast to the "obligation" provided for in Article 42 of the Workers' Statute, ${ }^{35}$ is a true obligation: failure to comply will result in sanctions. ${ }^{36}$ What is not regulated by this legislation is the mechanism to be used to carry out this verification, which is regulated in Article 42 of the Workers' Statute, and includes the possibility that the contracting employer may require a certificate that all social security obligations have been paid from the General Treasury of Social Security. ${ }^{37}$ The Ministry of Employment and Social Security has tried to resolve this shortcoming, implementing a mechanism similar to that provided for in Article 42 of the Workers' Statute: the Ministry authorises contracting companies to obtain online information on the social security affiliation and registration status of the workers employed by the contractors, although there is a requirement that the contractor companies authorise the General Treasury of Social Security to provide this information.

Along the same lines of action aimed at involving others in the prosecution of undeclared work, stemming from the idea that everyone should participate in the common goal of eradicating fraud, in August 2013 the Spanish Employment Minister Fátima Báñez announced the creation of a collaboration mechanism for this purpose: the mailbox to fight labour fraud. This measure was the first de facto introduction, without any legal foundations ${ }^{38}$ of a whistleblowing mechanism in Spain, namely, a mechanism for reporting an irregularity committed within a company to the competent authority. ${ }^{39}$

This collaboration method does not mean that the control of legality in labour matters will no longer be centralised in the Labour Inspectorate, since this body is responsible for the assessment of irregularities in labour matters. In fact, the mailbox only informs the Inspectorate of the commission of an irregularity, which means that it serves as a criterion for carrying out an inspection task.

According to the rules governing the activity of the Labour Inspectorate in Spain, it may act upon various different grounds: following an order from a higher authority, an order resulting from inspection

${ }^{31}$ On the measures introduced by this regulation, see ALEGRE NUENO, M. "Aspectos problemáticos de las nuevas medidas para combatir el empleo sumergido contenidas en el Real Decreto Ley 5/2011, de 29 de abril”. El Derecho, No 4/2012.

${ }^{32}$ On the problems of interpreting this legal text, see GUTIÉRREZ TRASHORRAS, "La nueva regulación de las infracciones y sanciones en materia de falta de alta, compatibilización indebida de prestaciones y el fraude en medidas colectivas", in CAMINO FRÍAS (coord.) et al. Lucha contra el empleo irregular y el fraude a la Seguridad Social. Thomson Reuters. 2013

${ }^{33}$ Indeterminate legal concept for which a definition has been attempted in the case law, considering said activity to be that which is "inherent" or "absolutely indispensable" for the business of the principal company, which is specified in the provision "works or services that belong to the productive cycle thereof", excluding complementary or non-core activities (inter alia, Supreme Court judgment of 15 November 2012, appeal for unification of doctrine No 191/2012).

${ }^{34}$ The concept of providing services on an ongoing basis is not defined by law, so a definition must be provided by the courts. In any case, it excludes occasional activities, which are not permanent.

${ }^{35}$ This precept provides for a similar "obligation" in the case of contracts related to the activity of the contracting company, which consists of the "duty" to verify that the contractor companies are up to date in the payment of their social security obligations (social contributions). The consequence of failing to observe this obligation, however, is only to lose the option to opt out of the joint and several liability provided for in the same article (in the event that, once the social security contributions certificate has been requested, the body in charge of issuing the certificate - the General Treasury of Social Security - does not reply within the 30 days established by law). There is therefore no sanction for any eventual breach of this obligation.

${ }^{36}$ Failure to comply with this obligation is classified as a serious administrative infringement in Article 22(11) of the Law on Labour Infringements (Royal Legislative Decree 5/2000, of 4 August) which is punishable by a fine of up to €6,250.626 (an infringement - hence a fine - being applicable to each of the affected workers).

${ }^{37}$ Mechanism approved by the Spanish Data Protection Agency (report 0047/2010 and report 412/2009)

${ }^{38}$ The only legal reference to this form of collaboration is found in the new law that regulates the Labour Inspectorate (Law 23/2015), which provides for cooperation with the Labour Inspectorate to be carried out preferably by electronic means (Article 18(3)).

${ }^{39}$ BELSITO, V., Il whistleblowing: tutele e rischi per il soffiatore. Cacucci editore. Bari. 2013. 
plans or programmes, at the reasoned request of other bodies, by virtue of a complaint or on the initiative of the Labour and Social Security Inspectors, in line with criteria of effectiveness and timeliness. ${ }^{40}$

Thus, a complaint as grounds for starting an inspection is provided for in Spanish legislation. In any event, this complaint cannot be compared with the complaint system via the anti-fraud mailbox: the complaint cannot be anonymous, since, according to the law, an anonymous complaint will not be processed. ${ }^{41}$ Conversely, the defining feature of complaints made through the mailbox is, precisely, their anonymity, with the purpose of encouraging the reporting of irregularities.

The legality problems and issues raised by anonymous whistleblowing go beyond the scope of this article. Suffice it to say here that this initiative has not been met with calm acceptance, ${ }^{42}$ since it does not seem to be in line with the opinion of the Spanish Data Protection Agency, a body that has spoken in favour of limiting anonymous complaints, claiming that confidential treatment may be offered through other mechanisms. ${ }^{43}$ In addition, the anonymous whistleblowing procedure does not even seem to respect the guidelines proposed by the Article 29 Data Protection Working Party, which recognises that anonymous reports pose a specific problem "with regard to the essential requirement that personal data should only be collected fairly". Therefore, the Working Party considers that, in order to satisfy this requirement, only identified reports should be communicated through whistleblowing schemes, admitting the possibility of anonymous complaints, but only exceptionally, concluding that the whistle-blower reporting systems should be established in such a way that they do not encourage anonymous reporting as the usual way to file a complaint. ${ }^{44}$

2.2 Measures to combat illegal employment. Once the existence of undeclared work has been verified, the promotion of regular employment requires that the detected irregularities be sanctioned.

a) Administrative sanctions. The most recent laws relating to sanctions for undeclared work have been aimed at increasing the size of administrative sanctions for undeclared work, although only in the case of sanctions related to the financial safeguarding of the social security system and not, however, for those related to the protection of workers' rights that may be violated. ${ }^{45}$

In this regard, Royal Decree-Law 5/2011, of 29 April, on measures for the regularisation and control of irregular employment and the promotion of housing rehabilitation, introduced, among the measures aimed at combating undeclared work, an increase in certain sanctions against employers. ${ }^{46}$ This increase affected, among others:

\footnotetext{
${ }^{40}$ Article 20(3) Law 23/2015.

${ }^{41}$ Article 20(5) Law 23/2015.

${ }^{42}$ This may be seen in the complaint made before the Ombudsman by the National Association for the Effective Defence of the Worker.

This association also filed a complaint with the Ombudsman about the incentive or compensation for the resolution of irregularities, as provided for in Clause 5(e) of the specific administrative clauses and technical conditions for the conclusion of a framework agreement with employment agencies for their collaboration with public employment services in the integration of unemployed people in the labour market, which demands that the procedure conclude with the imposition of sanctions for the incentive to be applied. (https://sede.sepe.gob.es/es/portaltrabaja/resources/sede/licitaciones/convocatorias/recursos/pdf/ PCAP 17 13.pdf)

This complaint, unlike the previous one, was heeded by the Ombudsman, who requested that the Spanish Government modify said incentive. The Ministry of Employment, however, refused to eliminate this incentive, aimed at combating irregularities that unemployed persons who are receiving unemployment benefits may commit. (https://www.defensordelpueblo.es/ resoluciones/incentivos-a-las-agencias-de-colocacion-2/)

${ }^{43}$ This could simply be preventing the defendant from knowing the name of the complainant.

${ }^{44}$ Opinion $1 / 2006$ on the application of EU data protection rules to internal whistleblowing schemes in the fields of accounting, internal accounting controls, auditing matters, fight against bribery, banking and financial crime. Doc. WP $117 \underline{\mathrm{http}} / / /$ ec.europa.eu/justice/policies/privacy/docs/wpdocs/2006/wp117_es.pdf

${ }^{45}$ Thus sanctions relating to violations of workers' rights remain unchanged, such as: the right to punctually receive payslips in the legally established form; to be informed in writing of the essential elements of the employment contract and of the main conditions of the employment arrangement; or the right to obtain a written contract of employment when required by law or by the worker him/herself. The same is true with infringements related to overtime or to working hours, for which sanctions have not been modified.

${ }^{46}$ GUTIÉRREZ TRASHORRAS, L. "La nueva regulación de las infracciones...” op. cit., pp. 191 et seq.
} 
- Sanctions related to infringements for failing to affiliate or register workers that start working for them, or for undertaking said proceedings late as a result of an inspection. ${ }^{47}$

- Sanctions related to infringements consisting of employing beneficiaries of or applicants for pensions or other regular social security benefits that are incompatible with working as a paid employee, when they have not been registered with social security prior to commencement of their activity. ${ }^{48}$

- Sanctions imposed for obstruction of the inspection when the aim of said inspection is to check the registration status of the workers who provide services in a company, as well as sanctions related to the breach of employer obligations, leading to the commission of the infringements referred to in the previous point. ${ }^{49}$

b) Additional sanctions. The increase in the size of the administrative sanctions stipulated for undeclared work has not been the only way to strengthen the State's punitive power against this offence. Other measures have been introduced, alongside those mentioned above, in the form of additional sanctions, also aimed at discouraging undeclared work.

The first additional sanction consists of the publication of the sanctions imposed for the aforementioned offences - once final - in order to make the identity of the offenders public and exposing them to public condemnation. This sanction is not immune from criticism. Firstly, because the principle of non bis in idem (double jeopardy) could be violated. Secondly, because of the risk of violating the principles of proportionality and legality, given the way in which the sanctions are established; ${ }^{50}$ and, finally, because of the potential violation of the right to the protection of personal data. ${ }^{51}$

Regarding this last point, it should be remembered that the fundamental right to data protection is intended to guarantee people control over their personal data, over their use and destination, so as to prevent the illegal trafficking of data and the damage this may cause to personal dignity. ${ }^{52}$

With regard to this sanction, no report has been published by the Spanish Data Protection Agency. However, in report 0550/2006, regarding the publication of sanctions in the field of sport, the agency considered that the publication of such sanctions, without the consent of the interested party, may only be considered under Article 11(2) of Organic Law 15/1999, on the protection of personal data (which provides for said publication when it is established by a legal instrument having the force of law), provided that it is a consequence of the nature of the penalty, without providing for the possibility of the general publication of sanctions. ${ }^{53}$

The second additional sanction for undeclared work is a toughening up of the exclusion of sanctioned companies from benefits provided for in employment promotion programmes (subsidies and credits on social contributions to be paid by the employer). Thus, in the case of companies that have

${ }^{47}$ Offence classified as serious in Article 22(2) of Royal Legislative Decree 5/2000, of 4 October, and punishable, after Royal Decree-Law 5/2011, with a minimum fine of EUR 3,126 to 6,250 (previously 626 to 1,250), with a medium fine of EUR 6,251 to 8,000 (previously 1,251 to 3,125), and with a maximum fine of EUR 8,001 to 10,000 (previously 3,126 to 6,250). Article 40 of Royal Legislative Decree 5/2000.

${ }^{48}$ Classified as a very serious offence, in accordance with Article 23(1) of Royal Legislative Decree 5/2000, which is punishable with a minimum fine of EUR 10,001 to 25,000 (previously 6,251 to 25,000), with a medium fine of EUR 25,001 to 100,005 (unchanged from previous amounts), and with a maximum fine of EUR 100,006 to 187,515 (also unchanged from previous amounts).

${ }^{49}$ In this case, the amount of the sanction is established under the terms indicated in the two previous footnotes, depending on whether the offence is classified as very serious or serious.

${ }^{50}$ Article 40(1) of Royal Legislative Decree 5/2000, of 4 August: "The sanctions imposed for very serious offences, once they are final, will be made public in the manner determined by law".

${ }^{51}$ See TOSCANI GIMÉNEZ, ALEGRE NUENO, in relation to a similar sanction related to risk prevention. "El Real Decreto de las sanciones por 597/2007 sobre infracciones de publicación en materia de Prevención de Riesgos Laborales muy graves es una norma inconstitucional" Aranzadi Social, No 6/2007, p. 5.

52 Judgment of the Constitutional Court 292/2000, of 30 November 2000, which recognised that "digital freedom" includes the right to control the use of data saved on a computer program (habeas data) and includes, among other aspects, the individual's opposition to certain personal data being used for purposes other than the legitimate purpose justifying the collection of said data.

${ }^{53}$ In the case of Article 40(1) of Royal Legislative Decree 5/2000, the regulation is limited to ordering the publication of these sanctions in the manner foreseen in a subsequent regulation, which has not yet appeared. 
been sanctioned for the infringement laid down in Article 23(1)(a) of Royal Legislative Decree 5/2000, ${ }^{54}$ the period of exclusion from enjoyment of said benefits was increased from one to two years by Royal Decree-Law 5/2011. Furthermore, this Royal Decree added a similar sanction in the cases of sanctions for the infringement laid down in Article 22(2) of Royal Legislative Decree 5/2000, ${ }^{55}$ although in this case the exclusion time is limited to one year, except in case of repeated offences, in which case the exclusion time is extended up to two years. ${ }^{56}$

This type of sanction was addressed in Law 13/2012, which sought to introduce more effective sanctions since, without aggravating the sanctions regime; this made it more just, thus reinforcing its deterrent power. In effect, although with this law the additional sanctions - consisting of the loss of aid provided when participating in employment promotion programmes - remained unchanged, this sanctions regime was required in order to better comply with the principle of proportionality. Thus, in the case of both the infringements related to the lack (or lateness) of the registration or affiliation of workers (Article 22(2) Royal Legislative Decree 5/2000) and the infringements related to the employment of beneficiaries of, or applicants for, pensions or other regular social security benefits that are incompatible with working as a paid employee, when they have not been registered with social security prior to the start of their activity (Article 23(1)(a) of the same legal instrument), the company will be sanctioned with the automatic loss of aid, credits and, in general, the benefits resulting from employment programmes "in proportion to the number of workers affected by the offence", ${ }^{57}$ targeting the benefits of greater amount over the benefits of lesser amount at the time of the commission of the offence.

Finally, the third additional sanction prescribed to discourage undeclared work consists of including the commission of the infringement laid down in Article 22(2) of Royal Legislative Decree 5/2000 in those situations that prohibit entering into government contracts. ${ }^{58}$ In this case, according to Article 61(2) of said regulation, the prohibition may not last for more than five years.

c) Criminal sanctions. The increased severity of sanctions for irregular employment has not only affected administrative sanctions, but has also had an impact on criminal sanctions. Thus, in criminal matters, Organic Law 7/2012, of 27 December, which modified the Criminal Code on transparency and the fight against tax and social security fraud, introduced various measures aimed at combating illegal employment using tax offences as the model and with the aim of strengthening the preventive dimension of criminalisation. ${ }^{59}$

This regulation reduced the amount applicable in cases of contributions fraud, or undue rebates or deductions, from EUR 120,000 to 50,000 in its definition of the crime of social security fraud.$^{60}$ This reduction was justified taking into account economic, political and social criteria, in response to the need to act firmly against behaviour that endangers the financial sustainability of the social security system. Behaviour that, in the opinion of the legislator, calls for emphatic condemnation in times of particular economic difficulty ( $\mathrm{p}$. IV of the preamble to the law).

\footnotetext{
${ }^{54}$ of their activity.

${ }^{55}$ Sanctions for not requesting, in a timely manner, the initial affiliation or registration of workers who begin working for them, the offence being applicable to each of the affected workers.

${ }^{56}$ Article 46(2) of Royal Legislative Decree 5/2000, of 4 August, with the wording established in Law 13/2012, of 26 December.

${ }^{57}$ Proportionality rule introduced in Article 46(1)(a) Royal Legislative Decree 5/2000, which aims to prevent a single offence of this type from giving rise to the loss of all the aid that the company could benefit from, making the number of workers affected irrelevant. See LÓPEZ PARADA, R.A., "Otras modificaciones introducidas en la Ley de Infracciones y Sanciones en el Orden Social por Ley 13/2012, de 26 de diciembre, de lucha contra el empleo irregular y el fraude a la Seguridad Social" in CAMINO FRÍAS (coord.) et al. Lucha contra el empleo irregular y el fraude a la Seguridad Social. Thomson Reuters. 2013, p. 303. LOPEZ PARADA describes the problems in enforcing this rule, mainly due to the impossibility of determining the number of affected workers and the comparison parameter for applying the rule of proportionality.

${ }^{58}$ Article 49(1) of Law 30/2007 on Public Sector Contracts (currently Article 60 of Royal Legislative Decree 3/2011, of 14 November) with the wording set down in Royal Decree-Law 5/2011.

${ }^{59}$ LOZANO ORTIZ, J.C., "El nuevo delito contra la Seguridad Social" in CAMINO FRÍAS (coord.) et al. Lucha contra el empleo irregular y el fraude a la Seguridad Social. Thomson Reuters. 2013, p. 340.

${ }^{60}$ Punishable by a fine and imprisonment from one to five years.
} 
In addition, Law 7/2012 introduced a new type of - aggravated ${ }^{61}$ - offence in certain cases of particularly serious behaviour as a result of the amount evaded (more than EUR 120,000) or for other concurrent circumstances of particular seriousness, such as fraud committed by a criminal organisation or group, or the use of individuals or corporations or entities without legal personality as intermediaries, businesses or fiduciary instruments or tax havens or tax-free territories, concealing or hindering the determination of the identity of the party subject to social security obligations or the perpetrator of the offence, the determination of the amount defrauded or the assets of the party subject to social security obligations or the perpetrator of the offence. In the case of this aggravated offence, and insofar as the maximum prison sentence was increased from five to six years, the statute of limitations for the offence was indirectly modified, and extended to 10 years.

In both cases (ordinary and aggravated offences) the prison sentence is accompanied by a fine and the loss of the possibility of obtaining public subsidies or aid and the right to receive benefits or tax incentives or social security payments during a period of four to eight years.

These are not the only developments that were introduced by Organic Law 7/2012. In line with efforts to combat the harmful effects of non-compliance with the obligation to pay social security contributions as a result of undeclared work, this law added a new offence applicable to those who simultaneously employ a large number of workers ${ }^{62}$ without registering them in the corresponding social security scheme or, as the case may be, without having obtained the corresponding work permit. These cases are punishable by fines and imprisonment of six months to six years.

To conclude the description of the developments introduced by Organic Law 7/2012 in the criminal field, it should be noted that in the case of criminal proceedings, and contrary to the case of administrative rules, the sanctions that have been toughened not only relate to the economic protection of the public social security system, but also to the protection of the rights of workers employed illegally. Thus the maximum deprivation of liberty rose from three to six years for those who, through deception or abuse of a situation of necessity, impose on their employees labour or social security conditions that harm, suppress or restrict the rights recognised by legal provisions, collective agreements or individual contract.

2.3 Measures to promote legal employment. Ultimately, the fight against undeclared work must promote legality, through certain instruments that create incentives for the regularisation of unreported employment. These instruments offer, under certain conditions, an "amnesty" for cases of non-compliance with the obligations arising from the employment contract.

This approach was used once before in Spain in 1997, to bring to light irregular temporary contracts. A form of amnesty was introduced in labour legislation to facilitate the transformation of fraudulent temporary contracts into permanent contracts. ${ }^{63}$ The mechanism allowed for the formalisation of an employment-promotion contract - a permanent contract that, as an incentive to recruitment, offered reduced compensation in the event of a dismissal for economic and business reasons found to be inadmissible - when concluded with workers recruited under fixed-term contracts until the year following the entry into force of the Royal Decree-Law that introduced this option..$^{64}$ Beyond that date, and for a period of four years, the contracts could be transformed under the terms provided for in the collective bargaining instruments. ${ }^{65}$

\footnotetext{
${ }^{61}$ Punishable by a fine and imprisonment from two to six years.

${ }^{62}$ Twenty-five percent in companies or workplaces that employ more than one hundred workers; fifty percent in companies or workplaces that employ more than ten and no more than one hundred workers; all employees in companies or workplaces that employ more than five and no more than ten workers.

${ }^{63}$ See ALBIOL MONTESINOS, I., La reforma laboral de 1997. Tirant Lo Blanch. Valencia, 1997, p. 57.

${ }^{64}$ Royal Decree-Law 8/1997, of 16 May.

${ }^{65}$ This period of amnesty was subsequently extended for successive periods. Thus, Royal Decree-Law 5/2001, of 2 March, provided for the possibility of converting temporary contracts formalised before 31 December 2003 into permanent employment-promotion contracts; Royal Decree-Law 5/2006, of 9 June, did the same with those formalised before 31 December 2007; and Royal Decree-Law 10/2010, of 16 June, with those formalised before 31 December 2010. Finally, Royal Decree-Law $10 / 2011$, of 26 August, allowed for the conversion of temporary contracts formalised before 31 December 2011 into permanent employment-promotion contracts. With this development, the amnesty would foreseeably have continued to be extended if it were not for the fact that Royal Decree-Law 3/2012, of 10 February, repealed the permanent employment-promotion contract, widening the scope of the incentive -compensation for unfair dismissal - that said contract entailed.
} 
Regarding irregular employment, Royal Decree-Law 5/2011, of 29 April, provided for the voluntary regularisation of undeclared work. It offered, in essence, the possibility, until 31 July 2011, of regularising the situation of those workers in respect of whom the initial affiliation or registration in social security had not been requested.

This voluntary regularisation was rewarded with an "amnesty" tion from administrative sanctions stipulated by Spanish law (Royal Legislative Decree 5/2000) for offences related to the irregular employment of workers for whom the initial affiliation or registration in social security had not been requested. This form of amnesty was subject to certain requirements. First, that the regularisation had to have been carried out within the stipulated time limit (by 31 July 2011). ${ }^{67}$ Second, that the regularisation was not related to situations of irregularity for which a social security action had already been brought against the company, or for which the Labour and Social Security Inspectorate had received complaints, claims or reports of any nature related to said situations in that company, or actions brought before the labour courts. Third, that the regularised work had been formalised through an employment contract with the worker, in any permanent or temporary or fixed-term contract modality, including training contracts ${ }^{68}$ in this case the initial duration of the contract could not be less than six months from the date of the application for registration with social security. ${ }^{69}$

Moreover, the amnesty affected certain provisions of the Workers' Statute regarding the rights of workers to be considered permanent workers under certain circumstances. Specifically, the amnesty expressly excluded the rebuttable presumption (iuris tantum) provided for in Article 15(2) of the Workers' Statute, by virtue of which the contracts of those workers who had not been registered with social security were considered to be permanent, unless proven otherwise, after a period equal to that which could have been legally established for the trial period. ${ }^{70}$

These measures were accompanied by others aimed at making the economic impact for the company as a result of the regularisation more bearable. In particular, it provided for the possibility of postponing social security contributions and for joint collection when registering the regularised situations.

However, Royal Decree-Law 5/2011 added a requirement, which, if omitted, entailed the loss of all these benefits. ${ }^{71}$ The first additional provision made the rights related to the amnesty conditional on the benefiting employers not terminating the contract of the workers affected by regularisation before six months. ${ }^{72}$

${ }^{66}$ SEMPERE NAVARRO and MARTÍN JIMÉNEZ do not consider that this measure is an amnesty inasmuch as it does not entail the cancellation of debts relating to social contributions or the exemption from liability for the payment of benefits, but is simply an exemption from administrative liability. SEMPERE NAVARRO MARTÍN JIMÉNEZ, El empleo sumergido: comentarios al Real Decreto-ley 5/2011 de 29 de abril. Valencia. Tirant lo Blanch. 2011, p. 52. However, page 57 states that this Decree-Law is "the first time that full acquittal (an "amnesty" in common parlance) for a clear and serious breach of labour and social security obligations had been introduced in the field of labour law".

${ }^{67}$ In contrast to the amnesty on fraudulent temporary contracts, the term for voluntary regularisation was not extended.

${ }^{68}$ Provided that the requirements for conclusion of the contract were met.

${ }^{69}$ A stipulation that could ultimately contradict the provisions on fixed-term contracts set down in Article 15 of the Workers' Statute (for example, with regards to the temporary contract, the regulation of which establishes a maximum duration that, in general, may not exceed six months from the increase in the temporary need for labour, this period would be exceeded if the regularisation was carried out through this contractual modality) or that would entail the regularisation process leaving out the option to apply for fixed-term contracts of less than six months (in this respect, see SEMPERE NAVARRO MARTÍN JIMÉNEZ, op. cit., pp. 66 and 67).

${ }^{70}$ Article 4(2) of Royal Decree-Law 5/2011. All other presumptions regarding employment contracts would not be affected by this Royal Decree-Law (for example, the presumption established in the event of non-compliance with the required written form of contract - Article 8(2) Workers' Statute - or in the event of evasion of the law (fraus legis) in temporary hiring - Article 15(3) Workers' Statute).

${ }^{71}$ The regulation, in such cases, stipulated the automatic loss of the right to receive the benefits established in the Royal Decree-Law, with effect from the date of regularisation. Moreover, it established the obligation to repay the aid, credits and general benefits resulting from the employment programmes obtained as a consequence of recruitment carried out within the framework of the regularisation. In addition, employers who failed to comply with the legal framework of regularisation were required to pay all applicable social security contributions; this without prejudice to the enforcement of sanctions established in Royal Legislative Decree 5/2000 and excluded by the amnesty.

${ }^{72}$ Excluding terminations due to disciplinary dismissal, or due to resignation, death, retirement, total or absolute permanent disability, or severe disability. 
In relation to this type of measure, Law 13/2012, of 26 December, put an end to another situation akin to these amnesties - if we consider the justification given by the legislator. Before this law, and in the event of non-payment of social security contributions, regulations provided for the automatic reduction of $50 \%$ of the amount of the sanction provided that the offender agreed to settle the amount in the legally stipulated period. After the 2012 reform, this reduction could only be applied in the event that the amount to be settled exceeded the amount of the initially proposed sanction. The justification that can be read into this regulation relates to the application of the principle of proportionality, which requires that the commission of the offence not be more beneficial to the offender than compliance with the rules that have been violated.

3. The effectiveness of the measures taken against irregular employment. Regrettably, in Spain, a transparent public mechanism has not yet been established to gauge the effectiveness of the aforementioned measures to combat undeclared work. Both Royal Decree-Law 5/2011 and Law 13/2012 provided for an evaluation of the outcomes with a view to introducing any necessary changes. ${ }^{73}$ In spite of these legal provisions, no official data on these evaluations have been published; all that has been published are some press releases by the Ministry of Employment and Social Security.

Regarding the effectiveness of the amnesty introduced by Royal Decree-Law 5/2011, the Opinion on the preliminary draft law to combat irregular employment and social security fraud ${ }^{74}$ stated that the measure did not seem to have had the expected result; in the absence of published results, this conclusion was inferred from the evolution of registration figures recorded during the amnesty period..$^{75}$

The press releases from the Ministry of Employment and Social Security, however, gave a more positive, optimistic account of the adopted measures, highlighting the number of contracts and bogus companies, and the number of regularised work contracts. Thus, the press release of 12 November $2012^{76}$ stated that in the period from January to October 2012, the plan to combat irregular employment had led to the detection of 1,174 fictitious companies (an increase of 443 per cent over the same period of the previous year). It also stated that the number of cancelled fake registrations - false employment contracts created to access benefits - had been 20,051 (55.19 per cent more than in October 2011). Lastly, it stated that a total of 16,254 inspections had been carried out, compared to 8,931 the previous year.

The press release of July $2014^{77}$ gave figures for 2012 and $2013,{ }^{78}$ evaluating the impact of the electronic mailbox against labour fraud, and highlighting the fact that this whistleblowing system had led to 4,359 inspection actions up to June 2014, which resulted in the uncovering of 1,097 jobs and the processing of cases to the tune of more than one million euros.

A positive outcome for this mailbox was again announced in the August 2015 press release, ${ }^{79}$ underlining its increased use compared to the first year of its existence and the "growing social awareness against these behaviours that undermine the balance of the labour market and the sustainability of the Welfare State".

The publication of the results in the fight against undeclared work as it is being waged does not seem to be the most appropriate approach, since it does not offer consistent evaluation parameters; and

\footnotetext{
${ }^{73}$ Six months after the entry into force of the regulation - 7 May 2011 - in the case of the Royal Decree-Law; and in the six months following 31 December 2013 in the case of the Law (Second Additional Provision and Sole Additional Provision, respectively).

${ }^{74}$ Work Commission on Labour Relations, Employment and Social Security. Economic and Social Council. 18 July 2012 (pages 4 and 5) http://www.ces.es/documents/10180/209618/Dictamen_032012

${ }^{75}$ A negative assessment of the measures proposed in Royal Decree-Law 5/2011 - on its generality, ambiguity and lack of realism - was given by Professor DE LA VILLA, who contended that the regulation had been passed without any real conviction in its effectiveness; he argued that it had been designed to be little more than a procedure from which, at best, some favourable statistics could be obtained. DE LA VILLA GIL, L.E., "La economía sumergida y los arañazos superficiales a la realidad social a través de las medidas adoptadas por el gobierno. Breve comentario al Real Decreto-ley 5/2011, de 29 de abril”. Revista General de Derecho del Trabajo y de la Seguridad Social, No 26/2011.

${ }^{76} \mathrm{http}: / /$ prensa.empleo.gob.es/WebPrensa/noticias/laboral/detalle/1810

${ }_{77} \mathrm{http}: / /$ prensa.empleo.gob.es/WebPrensa/noticias/Ministro/detalle/2264

${ }^{78}$ Information repeated in the following press releases:

- December 2014 (http://prensa.empleo.gob.es/WebPrensa/noticias/laboral/detalle/2388)

- April 2015 (http://prensa.empleo.gob.es/WebPrensa/noticias/ministro/detalle/2506)

${ }^{79} \mathrm{http} / /$ prensa.empleo.gob.es/WebPrensa/noticias/laboral/detalle/2615
} 
said results may also prove to be highly unreliable, as a consequence of the political interest in showing the positive effects of the measures adopted. The unreliability of this data is demonstrated by comparing the data on the mailbox from the Ministry of Employment and Social Security published in the months following the aforementioned press releases. Thus, by contrast with the data offered by the press release of July 2014, that data offered in the press release in August $2014^{80}$ is remarkably different; the latter press release stated that the mailbox to fight labour fraud, in its first year of operation, had enabled the Labour Inspectorate to initiate 8,192 inspections (4,359 was the number reported in July), unearthing 1,592 unreported jobs (1,097 in July) and clawing back a total of EUR 1.4 million in social security contributions.

Therefore, a thorough examination of the mechanisms to evaluate the measures adopted in the fight against undeclared work seems absolutely necessary for a rigorous and scholarly analysis of their effectiveness. This issue has been a constant complaint with all employment policies.

${ }^{80}$ http://www.lamoncloa.gob.es/serviciosdeprensa/notasprensa/mempleo/paginas/2014/220814buzonfraudeempleo.aspx 